\title{
The relationship between emotional and functional choices of club athletes in the context of employer brand and organizational attractiveness
}

\author{
Tuba TURAN HEVESLI
}

Institute of SocialSciences, KTO Karatay University, Konya, Turkey.

Address Correspondence to TT. Hevesli, e-mail: turanhevesli@gmail.com

\begin{abstract}
Being a part of an organization is one of the most important targets for every single individual. For this purpose, individual works and develops himself/herself. On the other hand, to provide its own prestige, choosing suitable and quality individuals is an important move. These mutual relations are explained with interest on an organization for employees or candidates. Values and image of an organization cause attractiveness for individuals that they want to be a part of it. This situation, which is called "organizational attractiveness", is defined with a brand, a name or attention on a specific symbol for individuals. In this process, emotional choices come forward and the expectations of individuals from organization are observed. Attention on a specific organization comes out with emotional factors mostly. At the same time, while individuals feel themselves as a part of an organization, they think about the benefits of that organization and they make their choices in this direction. In the sport world, the same thing is valid for the football players; the football players find the clubs that they feel themselves closer and support it as attractive and they think about benefits in the sportive image and financial mean as a part of that club. This study, in the basis of a survey, evaluates the attitudes of football players with the relations between organizational attractiveness, emotional and functional benefit. The outputs of study and survey unroll which factors important are for the choices of football player to play in a club.
\end{abstract}

Keywords: Attractiveness, emotional, football player, functional, organization

\section{INTRODUCTION}

Increasing level of selectivity of business world in competition process has caused competition and selectivity for staff selection. This competition and situation selectivity has not given chance to employees to choose the enterprises; in contrast, these facts have given more power to the companies to choose employees due to their interests. Although the enterprises has the authority to decide the employees' situation for the future, the characteristics and the specialties of an enterprise is effective on employees' decisions to choose an enterprise to work for. That is why, in the last years, the process, which is called "organization-employee fit", has come out. This process has become an important factor to achieve efficiency (15). The relationship between organization and employee, which depends on direct, positive and protection on mutual interests, have potential to create continuous achievement. At the same time, it creates chances for feelings organizational commitment with increasing potential of labor. That is why enterprises and employees are in search for a reasonable business relationship, which is compatible with their identities. Any of a negative process is not wished and enterprises and employees try to stay away from any of harms for their interests.

There is a mutual interaction in the organizational attractiveness issue. According to that, employers and employees have expectations from each other mutually; while the employers try to increase the popularity and the quality level of their enterprises to make it a preferred one, employees or candidates try to be a part of an organization, which is a target, and to show their identity as preferred employee for elite companies (8). Both sides work hard to be most preferred one. This situation creates opportunities for employers to be impressed by employees and for employees to be a prestigious person by taking the advantages of enterprises. Beside, enterprises have chance to add the other quality employees to their staff with the 
current quality ones in the structure of enterprise; this will introduce the names of enterprise to the public. After that, the enterprise will not need to declare the name and the purpose to collect the applications of candidates; the enterprise will be already collected the applications of best ones.

One of the triggering elements of organizational attractiveness is working opportunities, advantages and reward system. The reward for performances of employees will create a quality working environment and it will also assist employees to claim the enterprise's structure and identity in organizational mean and to feel the commitment to a structure; in other words, the quality level of opportunities for current employees will decide quality of future's candidates for enterprise (16). In particular, being different and deciding serious and sustainable targets are precious moves to be the leader in a sector as well to deploy quality employees (6); because every current and new members or candidates of an enterprise must increase their potential and quality level due to the high quality level of enterprise and this makes the election process easier. (14). Right in this point, the evaluations of Turban \& Keon (1993) are so important. Researchers state that the low capacity employees prefer minor enterprises; mid capacity employees prefer mid-level enterprises and high capacity employees prefer major enterprises to work; because they believe that they could suit the enterprises, which are compatible with their potential (11). With that way it was observed that there was a direct relationship between the level of organization and capacity and the situation of employees in the organization and their support to organization. If the level of targets and the wish to be effective in the market increase, the level of employees' quality and their support to the organization increase, too.

The ideas and the perception of employees about themselves have great importance about organizational attractiveness. In particular, the people, who will make job application, care about the situation of organization; if there is not any extremely negative fact, they can feel a part of an organization and they decide about their job application. When it is considered from a different angle, the employees, who are sure about their capacity, have potential to find the enterprise, which is compatible with his/her. Beside, a candidate may see himself/herself as the potential part of an enterprise without a job application and with that he/she can do anything possible to be a real part of that enterprise during the application process. When an individual is aware of his/her capacity, this awareness is effective to decide the quality and individuals decide a roadmap for their future in the business world (8). Whatever the situation and the position of organization, the key factor is the selfawareness and self-conditioning for the adaptation process to an organization. In the end, there is certainly a separation between minor and major enterprises for employees and candidates. According to that if the employees are sure about their own capacity and if it is on the high level, they surely want to be a part of a prestigious and major enterprise; because the general perception is that the major organizations had potential to present more opportunity and more modern working areas for their employees (4). According to the researchers, who developed approaches on that this situation was a part of organizational culture, all the activities, which were realized by an enterprise to make itself attractive, become a routine and a specialty of that enterprise. With that way, organizational culture provides an organizational attractiveness effect with the effect of prestige that it created (12). The concepts and the positive facts such as the prizes that an enterprise gained, its market achievement and interest rates have determinative effect on candidates' criteria of choice (1).

\section{Organizational attractiveness in the context of emotional and functional choices}

Right in this point, personal emotional motives and their reflections on attitudes gain importance. Individually, a person is a supporter of something, a fact or a creation. That is why, a person absolutely feels that he/she had to be a part of a side. Even the issue is on business world, a person feels that he/she had to work and to be a part of an enterprise emotionally. This is an important factor in marketing, too and the enterprises try to create loyal customers during the promotion activities to sell their own products. At the same time, the enterprises expect the current customers' loyalties to encourage the other customers (5). The enterprises try to create an emotional and functional supportership. It is the same thing in business world; a candidate wants to be a part of an enterprise, which is the favorite one for that candidate, due to his/her own potential. This is similar with being a supporter and deciding a side to be a part of it (8). The reason of an employee's wish to work for a worldwide famous company and 
to try to be part of it, which has an office in that employee's country, is about the wish to be in that organization emotionally and the expectation to get the advantages of that organization for its current employees (7).

Emotional intelligence is one of the factors, which directs the behaviors of human being, and it is the determinative factor for a person to like or to hate something; with that way, people decide about their side, the support they showed and the reason of their struggle in their minds (3). However, functionally, self-value of people, which is decided due to their own expectations, assist the emotional intelligence to be more evident and assist the individual to choose side that they would struggle to be a part of it (10). Combination of these factors clarify the facts, which are supported by individual himself/herself. This situation shows itself in the efforts to be a part of an organization. The individual encourages himself/herself as a part of the organization that the individual feels himself/herself close to it emotionally and that individual decide about a road map for the future. In time, the individual attempts to make that role suitable for himself/herself and to be a real part of organization.

There are two important factors to consider; first of all, the individual separates the factors, which were decided before, with a selective viewpoint in time and that individual focuses on just one target. The individual efforts to be compatible the criteria of a specific target to reach the target point. In the basis of business life, individual decides a road map for himself/herself to be a part of an organization and to be compatible with the necessities of that organization; with that way the individual prepares himself/herself for a possible position in the organization. Even that individual cannot reach the position, which is expected, he/she is already aware of his/her potential and with that that individual keeps the emotional viewpoint (3).

The second factor is related to interests of individual. Although the individual has organizational commitment feelings and wish to stay as a part of organization, that individual may seek the maximum benefit level in another organization; with that way, the individual thinks functionally and expects to be a part of an organization, which can present financial benefits with the strong effect of emotional bond (3).
The feelings such as commitment and interest are the most striking points of individuals' expectations. These feelings have supportive and encouraging role on individuals to be prepared to be a part of an organization. In the current conditions of business world, being a real part of an organization, firstly, is related to loving an organization, being a supporter of it and being a servant of it. The individuals, who have commitment feelings for their organization inside and outside of organization, have effect to increased quality and recognition levels or their organization. That is why the organizations must make their image preferable, supportable, alive, effective and attractive. In particular, in the business world, there is not just competition in the production and marketing processes; there is also a competition for introducing the image of organization and for bringing the qualified individuals to the organization during the effective competition process. That is why enterprises, organizationally, must design their human resources strategies in realistic way. In other words, the enterprises wait for candidates' applications due to the opportunities for their employees; it will be really hard to expect the qualified employees to work for featureless and physically low scale organizations (9).

When the issue was evaluated in the basis of sport organizations, the situation is highly the same. According to that when the athletes were in a process to make a decision for the club that they wanted to play for or to decide a target for their future, highly they prefer to play for the clubs that they supported. This is the same for football, which is followed by billions of people all around the world. Football players want to be a part of the team that they supported and they want to achieve something with that team at least once time during their football career. This comes out with the feeling of organizational attractiveness of football player, who see themselves with the jersey, the badge and the club that they supported. Sometimes colors, sometimes the name of a popular player and sometimes achievements cause a conditioning for players to be in the organization that they wished to be in. In particular, achievements of a club cause an identification for players and this encourages the players to struggle for being a part of team. The players, who focus on their targets and have selftrust, try to reach their goals and to increase their sportive quality level. 
Until this time, the situation defines a process that a player sees himself/herself as a part of a side and shapes his/her actions. Although player sees himself/herself as a part of a side, functionally, it will be compatible with the interests of player to be a part of football club, which has more potential than the team that football player currently supports. With that way, functionally, choosing the team with a professional approach, which is compatible with the interests of player, will be a necessity for player's career more than a choice.

Absolutely, all the football player want to struggle for the best football clubs. However, current situation, popularity and achievements of a club that football players are in trigger the commitment of players. After that, these facts will assist the player to feel himself/herself as a part of organization and supporter. The achievements of club, in the highly competitive leagues and tournaments, during the decision-making process of transfer, will direct the choices of players to play in the successful club. In other words, the club will not have to choose a player, there will be a sphere for clubs to be chosen. Football player will feel organization attractiveness, emotionally that player will the supporter of that club, functionally that player will feel pleasure to be a part of that club and that player will have benefit in any way.

\section{MATERIAL \& METHOD}

The research has been designed as scanning model and a field research has been made with athletes. The research has been made with the athletes, who belong to various sport clubs in city of Konya. The five-article scale, which was developed by Turban \&Keon (1993), was used in the research to decide the perception of attractiveness of athletes and the other scale, which has been created by scanning the related literature, to decide personal functional and emotional choice specialties of athletes(11). In this research, general reliability of organizational attractiveness scale has been found as 0,892 and high. Ünal's research and the related literature assisted to create the scale of emotional and functional choices(13). The expressions in scale were adapted to decide the emotional and functional choices of athletes. The study of reliability and validity was made. "Cronbach Alpha", which is the internal consistency coefficient, was calculated to calculate the reliability 18 articles in the scale of emotional and functional choice. The general reliability of scale has been found as alpha $=0.923$ and very high. The method of explanatory factor analysis was applied to put forth the construct validity of scale. In the end of Barlett test $(p=0.000<0.05)$, there was identified a relationship between the variables, which were used in factor analysis. In the end of test $(\mathrm{KMO}=0.868>0.60)$, it was identified that the size of sample was sufficient for factor analysis. Researchers achieved to stay the structure of relationship between factor same by choosing varimax method in factor analysis. In the end of factor analysis, the variables were brought together under three different factors that their variance was explained as \%63.783. According to alpha, which was found as related to reliability, and explained variance, it was understood that the scale of emotional and functional choice was a valid and a reliable tool. The factor structure, which belongs to scale, can be seen below.

In the factor analysis evaluation of emotional and functional choice scale, there was paid attention on handling the factors that its self-worth was greater than one; on keeping the factor loads, which show the weightiness of variables in factor, high and on keeping the factor loads away from each in the same variable. Because of the factors, which create the scale, were not named, the general point of scale was used in the research.

The data, which were collected in the research, were analyzed by statistic program package. During the evaluation process of data, descriptive statistical methods (number, percent, mean, standard deviation) were used. The "t-test" was used in comparison of quantitative data and "One Way Anova Test" was used in the comparison of parameters between the groups when there were more than two groups. The relationship between variables of research was tested with "Pearson Correlation Test". Findings were evaluated in \%95 confidence interval and in \%5 meaningfulness level.

\section{RESULTS}

In this chapter, there are the findings, which came out with the analysis data that researchers collected from the participant athletes via scales. There are explanations and comments, which depend on findings. 
Table 1. Factor structure of emotional and functional choice scale.

\begin{tabular}{|c|c|c|c|c|}
\hline Dimension & Article & Factor & Described Variance & Cronbach's Alpha \\
\hline \multirow{12}{*}{$\begin{array}{l}\text { F1m } \\
(\text { Eigenvalue=8.197) }\end{array}$} & Functional and Emotional Values 14 & 0.879 & \multirow{12}{*}{34.842} & \multirow{12}{*}{0.934} \\
\hline & Functional and Emotional Values 10 & 0.801 & & \\
\hline & Functional and Emotional Values 15 & 0.767 & & \\
\hline & Functional and Emotional Values 8 & 0.755 & & \\
\hline & Functional and Emotional Values 17 & 0.732 & & \\
\hline & Functional and Emotional Values 18 & 0.728 & & \\
\hline & Functional and Emotional Values 6 & 0.723 & & \\
\hline & Functional and Emotional Values 11 & 0.697 & & \\
\hline & Functional and Emotional Values 13 & 0.623 & & \\
\hline & Functional and Emotional Values 16 & 0.602 & & \\
\hline & Functional and Emotional Values 7 & 0.520 & & \\
\hline & Functional and Emotional Values 12 & 0.482 & & \\
\hline \multirow{3}{*}{$\begin{array}{l}\mathrm{F} 2 \mathrm{~m} \\
(\text { Eigenvalue=2.265) }\end{array}$} & Functional and Emotional Values 5 & 0.747 & \multirow{2}{*}{14.738} & \multirow{2}{*}{0.635} \\
\hline & Functional and Emotional Values 9 & 0.642 & & \\
\hline & Functional and Emotional Values 1 & 0.819 & \multirow{4}{*}{14.203} & \multirow{4}{*}{0.797} \\
\hline \multirow{3}{*}{$\begin{array}{l}\text { F3m } \\
\text { (Eigenvalue=1.019) }\end{array}$} & Functional and Emotional Values 2 & 0.810 & & \\
\hline & Functional and Emotional Values 3 & 0.794 & & \\
\hline & Functional and Emotional Values 4 & 0.584 & & \\
\hline
\end{tabular}

Table 2. Distribution of club athletes' demographic specialties.

\begin{tabular}{llcc}
\hline & Groups & $\mathrm{f}$ & $\%$ \\
\hline Age & $18-25$ & 81 & 80.2 \\
& $26-30$ & 20 & 19.8 \\
& Total & 101 & 100.0 \\
Marital Status & Married & 16 & 15.8 \\
& Single & 85 & 84.2 \\
& Total & 101 & 100.0 \\
Education Level & Middle School & 17 & 16.8 \\
& High School & 74 & 73.3 \\
& University & 10 & 9.9 \\
Professional Experience as an Athlete & Total & 101 & 100.0 \\
& 1-5 Year & 44 & 43.6 \\
& 6-10 Year & 35 & 34.7 \\
& More than 10 Year & 22 & 21.8 \\
Time Period Spent At The Club & Total & 101 & 100.0 \\
& 1-3 Year & 83 & 82.2 \\
& More than 3 Years & 18 & 17.8 \\
& Total & 101 & 100.0 \\
\hline
\end{tabular}

Table 3. The levels of emotional functional choice and organizational attractiveness.

\begin{tabular}{lccccc}
\hline & $\mathrm{N}$ & Mean & SD & Min. & Max. \\
\hline Emotional Functional Choice & 101 & 3.220 & 0.715 & 1.830 & 4.610 \\
Organizational Attractiveness & 101 & 3.553 & 0.949 & 1.600 & 5.000 \\
\hline
\end{tabular}

In the research, 81 of athletes $(\% 80,2) 18-25$ year-old, 20 of athletes $(\% 19,8)$ 26-30 year old; 16 of athletes $(\% 15,8)$ married, 85 of athletes $(\% 84,2)$ single; 17 of athletes $(\% 16,8)$ secondary school graduated, 74 of athletes $(\% 73,3)$ high school graduated, 10 of athletes $(\% 9,9)$ university graduated; 44 of athletes $(\% 43,6)$ have $1-5$ year experience, 35 of athletes $(\% 34,7)$ have $6-10$ year experience, 22 of athletes $(\% 21,8)$ have more than 10 year experience as professional athlete; 83 of athletes $(\% 82,2)$ have spent $1-3$ year, 18 of athletes $(\% 17,8)$ have spent more than 3 years at their club.

Participant athletes' level of "emotional functional choice" was determined as mid (3.220 \pm 
0.715) and their level of "organizational attractiveness" as high (3.553 \pm 0.949$)$.

In the research, it was determined that the emotional functional choice and the level of organizational attractiveness do not show any meaningful difference due to variables such as educational level, professional experience as an athlete, time period spent at the club, marital status and age $(\mathrm{p}<0.05)$.

In the research. it was found that there was a meaningful relationship between organizational attractiveness and emotional functional choice in statistical mean $(r=0.809 ; \mathrm{p}=0.000<0.05)$. When emotional and functional choices increased. organizational attractiveness increases positively.

\section{DISCUSSION}

In the organizations. which develop as depending on human resource. the importance of image of organization and the quality of organization in the minds of current employees as an employer brand and candidates as a perception increase day by day. The concept of employer brand. which has been popular since the 2000s. is not just valid for the current employees and the candidates; it is also valid for institutionalized organization formations. The sport clubs are in this institutional organization formations as an example.

Table 4. The comparison between emotional functional choice and organizational attractiveness due to demographic specialties.

\begin{tabular}{|c|c|c|c|c|c|c|}
\hline & Group & $\mathrm{N}$ & Mean & SD & $\mathrm{F}$ & $\mathrm{p}$ \\
\hline \multicolumn{7}{|l|}{ Educational Level } \\
\hline \multirow[t]{3}{*}{ Emotional Functional Choice } & Middle School & 17 & 3.095 & 0.732 & 1.291 & 0.280 \\
\hline & High School & 74 & 3.285 & 0.712 & & \\
\hline & University & 10 & 2.950 & 0.681 & & \\
\hline \multirow[t]{3}{*}{ Organizational Attractiveness } & Middle School & 17 & 3.541 & 0.910 & 0.884 & 0.416 \\
\hline & High School & 74 & 3.605 & 0.979 & & \\
\hline & University & 10 & 3.180 & 0.763 & & \\
\hline \multicolumn{7}{|l|}{ Professional Experience as an Athlete } \\
\hline \multirow[t]{3}{*}{ Emotional Functional Choice } & 1-5 Years & 44 & 3.259 & 0.691 & 1.933 & 0.150 \\
\hline & $6-10$ Years & 35 & 3.332 & 0.730 & & \\
\hline & More than 10 Years & 22 & 2.965 & 0.706 & & \\
\hline \multirow[t]{3}{*}{ Organizational Attractiveness } & $1-5$ Years & 44 & 3.555 & 0.753 & 2.256 & 0.110 \\
\hline & 6-10 Years & 35 & 3.760 & 1.143 & & \\
\hline & More than 10 Years & 22 & 3.218 & 0.909 & & \\
\hline \multicolumn{7}{|l|}{ Time Period Spent At The Club } \\
\hline \multirow[t]{2}{*}{ Emotional Functional Choice } & $1-3 Y_{11}$ & 83 & 3.204 & 0.759 & -0.477 & 0.522 \\
\hline & 3 YildanFazla & 18 & 3.293 & 0.466 & & \\
\hline \multirow[t]{2}{*}{ Organizational Attractiveness } & $1-3 Y_{11}$ & 83 & 3.535 & 0.985 & -0.397 & 0.692 \\
\hline & 3 YildanFazla & 18 & 3.633 & 0.783 & & \\
\hline \multicolumn{7}{|l|}{ Marital Status } \\
\hline \multirow[t]{2}{*}{ Emotional Functional Choice } & Married & 16 & 3.024 & 0.687 & -1.197 & 0.234 \\
\hline & Single & 85 & 3.257 & 0.718 & & \\
\hline \multirow[t]{2}{*}{ Organizational Attractiveness } & Married & 16 & 3.475 & 0.955 & -0.354 & 0.724 \\
\hline & Single & 85 & 3.567 & 0.953 & & \\
\hline \multicolumn{7}{|l|}{ Age } \\
\hline \multirow[t]{2}{*}{ Emotional Functional Choice } & $18-25$ Years & 81 & 3.261 & 0.716 & 1.171 & 0.244 \\
\hline & More than 25 Years & 20 & 3.053 & 0.703 & & \\
\hline \multirow[t]{2}{*}{ Organizational Attractiveness } & $18-25$ Years & 81 & 3.593 & 0.957 & 0.854 & 0.395 \\
\hline & More than 25 Years & 20 & 3.390 & 0.923 & & \\
\hline
\end{tabular}

Tablo 5. The relationship between levels of emotional functional choice andorganizational attractiveness.

\begin{tabular}{llcc}
\hline & & Emotional Functional Choice & Organizational Attractiveness \\
\hline Emotional Functional Choice & $\mathrm{r}$ & 1.000 & \\
& $\mathrm{p}$ & 0.000 & 1.000 \\
Organizational Attractiveness & $\mathrm{r}$ & $0.809^{* *}$ & 0.000 \\
& $\mathrm{p}$ & 0.000 & \\
\hline
\end{tabular}


It is believed that there is certainly a sport club in the heart of every athlete as well as there is certainly an employer brand in the heart of every employee. There must be sub factors of an enterprise to create a permanent image as employer brand. Lievens \& Highhouse (2003) states that the image of employer brand has functional and emotional specialties(6). The various expressions. which belong to organization. intangible and subjective. create the emotional choices. The feeling of "finding the struggle on the field or on the pitch with the team towards thousands of fans as exciting" may be shown as example for this. The specialties such as concrete and felt create the specialties of functional choice. The chance of players to reach the health services in the contracted hospital during the injury and disease process is an example for that.

Organizations try to create a gravitational force in the competition environment to have advantage. to protect their force and to bring qualified labor. It is the same for the sport clubs such as the other organizations and they try to bring successful players or the players. who have potential to be successful. to their organization. The great clubs have more potential to have this gravitational force. Organizational attractiveness can be measured as an individual's degree of attention and admiration and it is decided due to individuals' perception. In this research. which was shaped with the interviews that they were made with the 101 football players in various clubs in Konya. it was observed that there was a direct relationship between organizational attractiveness and emotional and functional benefit choices and when the emotional and functional benefit choices of players increased. the organizational attractiveness increases highly. According to that. the individuals. who decide a road map for the future. were in process to decide about most appropriate club between the football clubs in their city. In regional. national and international field. when the level of football players' expectation increased. when the frame of their plans enlarged and when their emotional and functional ideas were added to this process. the organizational attractiveness increases in the same way. In particular. the teams. which struggle in the high level organizations in Konya. increase the football players' sense of participation in regional mean.

According to outputs of research. the emotional and functional choices do not have similarity or proximity due to football players' demographical specialties. Mostly. whatever the football players' demographical specialties are. the most important factors to decide the emotional and functional choices of football players are their emotional expectations. their wishes and their ideas for the future. Rather than the basic variables such as age range. educational level or marital status. personal approaches have more determinative role to decide the emotional and functional choices.

At the same time. it does not show any similarity or proximity about organizational attractiveness due to football players' demographical specialties. The most considered issue in organizational attractiveness as in the emotional and functional choices is the viewpoint of football players towards the football club. their expectations. their loyalty to the club and the current situation of club.

According to the analysis of data. it was observed that the emotional and functional choices of football players are on the mid-level. On the other hand. the football clubs in Konya meet these choices on the mid-level. After all. firstly. the individuals. who play football in Konya increase the level of their expectations to play for a club in Konya. At the same time. regionally. there is a serious attractiveness level of local football clubs for local players. The reason is that the local football players planned to play football in their own region's football clubs.

\section{REFERENCES}

1. Bakanauskiene I, ZalpyteLina, Vaikasiene J.Employer's attractiveness: employees' expectations vs. reality in lithuania. Human Resources Management \& Ergonomics.2014; (8)1.

2. Daniel B. Turban, Kenon TL. Organizational attractiveness: An interactionist perspective. Journal of Applied Psychology,1993:78(2): 184-193.

3. Hendrie Weisinger. İş Yaşamında Duygusal Zeka (çev. Nurettin Suleymangil). İstanbul: MNS Yayıncılık. 1998.

4. IsenhourL, Kimberly C, Lukaszewski M, Stone DL. Organizational attraction factors: A technology perspective. Journal of Technology Research,2014; 5: 1-12.

5. İsmet Mucuk. Pazarlama İlkeleri. İstanbul: Türkmen Kitabevi, 2009.

6. Lievens F, Highhouse S. The Relation of Instrumental and Symbolic Attributes to a Company's Attractiveness as an Employer. Personel Psychology,2003;53: 75-102.

7. Mehmet Şişman Örgütler ve Kültürler. Ankara: Pagem A Yayıncılık, 2002.

8. Müge Leyla Yıldız. Algılanan kişi-örgüt uyumu, taninirlik, imaj, örgütsel çekicilik ve işe başvurma niyeti arasindaki ilişkilerin yapisal eşitlik modellemesi ile incelenmesi. Marmara Üniversitesi İ̈B Dergisi, 2013; 1: 153-173. 
9. Sanskrity J. Susmriti S, Khan KA. Organizational Attractiveness as a predictor of Employee retention. OSR Journal of Business and Management (IOSR-JBM), 2014; (16)9: 41-44.

10. Tamer Koçel İşletme Yöneticiliği (10. Basım) İstanbul: Arıkan Yayincllik, 2005.

11. Turban DB, Keon TL. Organizational attractiveness: An interactionanlist perspektive. Journal of Applied Psychology, 1993; 78(2): 184-193.

12. Udofot PO, Inyang EB, Akpan AP. Perception on Organisational Attractiveness: An African Sample. British Journal of Economics. Management \& Trade,2015: 7(2): 148157.
13. Ünal AN. İşveren Markası Kavramı Bağlamında Fonksgijyonel Ve Duygusal Tercih Özelliklerinin Örgütsel Bağlılık İlişkisi: Hava Harp Okulu Örneği. Yayımlanmamış Yüksek Lisans Tezi. İstanbul, 2010

14. William N, Naomi A. Gardberg L, Belkin Y. Journal of International Business Studies, 2006; (37)5: 666-686.

15. Yasemin Arbak, Yeşilada T. Örgüt kişi uyumu ve örgütsel çekicilik: hangi kişiler ne tür örgütleri daha çekici bulur? Journal of Istanbul Kultur University,2003; 3: 23-37.

16. Yasemin Arbak,Duygulu E, Uyguç N.Örgütsel çekicilik. İTÜ Ulusal Yönetim Dergisi,1995; (3)7: 38-50. 